\title{
Editorial
}

\section{Anaesthesia oral examination}

In their paper, "The oral examination in anaesthetic resident evaluation" in this edition of the Journal, Eagle, Martineau and Hamilton present a useful balanced view of an examination that remains perhaps the most controversial available technique for skill or knowledge assessment.

The authors point out the widespread use of some form of oral examination in the specialty of anaesthesia throughout the English speaking world. Although the process may vary, the generic structure is often similar. Theoretically, the outcome is an evaluation of the candidate's ability to problem solve, to communicate skills and to display knowledge. It is the rare candidate who does not think back over his/her oral examination experience and remember it with some degree of loathing. I would doubt that more than a handful of candidates have ever regarded the actual examination as a generally positive experience per se.

At the completion of their experience many candidates will decry the exercise as not representing "real life," not truly testing the clinical ability and being such an artificial situation that little extrapolation can be made to the clinical operating room environment. All of these criticisms are valid and were this measurement of "competence" done purely as a simulation of such an environment, there would be strong reasoning to abolish the oral examination format completely. But, as the authors point out, there is more to the oral examination than just the simulation of a clinical situation.

A major question is the validity of the examination. An examination must have appropriate content. It must be credible in what it tries to assess. It should be able to differentiate between experienced and poorly prepared candidates. These aspects, as well as being able to achieve the same measure of a candidate's abilities when that candidate is examined at different times by different examiners create a milieu of doubt in the minds of many anaesthetists and educators and most candidates around the oral examination.

From the Department of Anaesthesia, McMaster University, Faculty of Health Sciences, Executive Vice-President, Medical Services, St. Joseph's Hospital, Hamilton.
Moreover, the emotional involvement for the candidates adds to the feelings of distrust of the process. By definition a candidate appearing for certification oral examination must be nearly 30 . Most physicians have been academically superior students and very few, in today's educational environment, have ever experienced serious failure. For many, the stakes are enormous. After as much as 13 years of higher education and often a considerable financial outlay, a bright student who has been led by society to consider her/himself a superior individual, faces a very real possibility of failure. To some this may mean an inability to take up a promised position at a time when physician "jobs" are becoming increasingly difficult to find. In some provinces it may mean a failure to receive a billing number. It may even mean an inability to be licensed as a physician.

This is all especially provoking to candidates who have already suffered through and successfully completed the multiple-choice question part of the examination and who have received a satisfactory final in-training evaluation report (FITER) from a programme director who has spent years carefully evaluating a candidate's performance.

There is also the cost of the oral examination process. The time and energy of the examiners who give up weeks of their time to exhaust themselves at minimal remuneration are considerable. For candidates, the registration fee plus travel and accommodation can be a burden.

What, then, is the value of all this and why do we perpetuate the oral examination? Eagle et al. point out that the measure of clinical competence which oral examiners attempt to measure consists of more than just the ability of a candidate to respond by rote to an imaginary clinical situation. The process is intended to attempt to evaluate a combination of clinical skills learned by experience with specific knowledge and interpersonal skills all integrated to solve and treat a medical problem. The oral examination is the final attempt by a national body responsible for setting standards (the Royal College of Physicians and Surgeons of Canada) to take a measure of the candidate as a "Compleat Anaesthetist" (to paraphrase Sir Isaac Walton).

The question is whether the oral examination process can successfully achieve this end. The format differs some- 
what from country to country. The American experience is a cold impersonal one allowing for little discussion or review between examiners and requiring that all candidates at a given time be asked exactly the same questions. Because of the short time allotted, the candidates thought process and discussion skills are of little interest to the examiners. The specific of the answer is all-important. The Canadian examination starts from a generalized area but develops and may be constricted depending upon the way in which a candidate responds. This is functional because of the smaller number of candidates and the presence of all the examining board during the final review and grade assignment at the end of each day. That personal touch and individual latitude permits candidates a margin of safety with regard to nervous tension or confusion which are not present in the American Board of Anesthesiology process. As well, the presence of a third examiners, acting as scribe, to be an objective third party in the case of a split decision adds immeasurably to the process.

The authors review the way that the validity and reliability of the U.S. system have been measured and improved. In particular they note the value of setting standards for examiners and designing training programmes and evaluation tools for examiners as well as for candidates.

Herein, perhaps, lies the way that the oral examination process in Canada will continue to be a viable respected form of candidate evaluation. The days of an examiner putting a candidate through a process of humiliation as a step towards adulthood are long gone. No more may an examiner fail a candidate because the candidate suggested a technique differing from that of the examiner. Firstly and most important, the ethos of the examination setup must be one of collegiality. The Royal College of Physicians and Surgeons of Canada itself reminds examiners that in the process of certification, the oral examination is the final step. Other hurdles have been completed and programme directors feel the candidate has reached a Fellowship level of practice. The oral should be an acknowledgement of that.

Next, there has been a concerted effort over the past decade to insert a degree of humanity into the process. Every attempt is made by the examiners to be kind, courteous and on time. The team previews questions in advance and the use of the "grid" assists in avoiding repetitious questions and allowing as wide a range of pertinent material to be covered as possible. It is important that ludicrously complex situations are now considered inappropriate.

Should the oral examination continue? The answer is yes provided that: (a) An ongoing effort be made to educate candidates about the purpose, structure and evaluation criteria of the process. The rumour mill of fear is the greatest enemy of a candidate coming to an oral.

(b) The examining board continues constantly to review, improve and educate itself adopting new proved evaluation techniques and striving always for greater objectivity and all the various forms of validity.

(c) The examining board apply to itself the same rigorous assessment criteria it applies to the candidates in reviewing the performance of its members.

Finally, I would support the authors' statement that the greatest strength of the oral examination is not as a measurement instrument but as a teaching device. The greatest positive feedback to the process comes from frequent comments made by candidates, usually one to two years after finishing the process, that the preparation for the oral gave a greater command of the specialty, not just in book knowledge or technical ability, but in being able to integrate ideas and communicate those ideas to others. I would challenge today's examining board to design an instrument to measure this hypothesis and would suggest that such a tool is necessary to ensure the continuance of the oral examination.

\section{L'examen oral en anesthésie}

Dans ce Journal, vous trouverez sous la plume de Eagle, Martineau et Hamilton, un article intitulé « The oral examination in anaesthetic resident evaluation ". Les auteurs émettent une opinion réfléchie et pratique sur un mode d'évaluation qui demeure encore la plus discutée des méthodes d'évaluation des habiletés et connaissances.

Ces auteurs attirent notre attention sur l'usage répandu des examens oraux en anesthésie, sous une forme ou une autre, dans les pays anglo-saxons. Bien que le processus puisse varier un peu, la structure générale est le plus souvent la même. En théorie, l'objectif ultime de cet examen consiste à évaluer l'habileté du candidat à solutionner des problèmes, transmettre sa compétence et faire la preuve de ses connaissances. Rares sont les candidats qui se souviennent de leurs oraux sans répugnance. Je suis à peu près sûr que très peu de candidats ont regardé l'examen actuel comme une expérience positive.

Après l'examen, les candidats vont plutôt dénigrer l'exercice sous prétexte qu'il ne représente pas la vraie 
vie, qu'il n'évalue pas réellement l'habileté clinique et que la situation est tellement artificielle qu'elle ne permet pas d'extrapolation à la clinique. Ces critiques sont valides et si l'évaluation de la compétence consistait simplement en la simulation d'une aventure clinique, l'argument pour l'abolition de cette forme d'évaluation, deviendrait pratiquement irrésistible. Toutefois, comme le font remarquer les auteurs du texte, il y a plus dans l'examen oral qu'une simple simulation de la clinique.

La validité de l'examen demeure une question primordiale. Son contenu doit être approprié et plausible avec ce qu'il veut évaluer. Il doit être capable de distinguer entre le candidat bien préparé et celui qui ne l'est pas. Ses caractéristiques doivent permettre une évaluation identique des habiletés à différents moments et par différents examinateurs. A défaut de quoi, ils maintiendront un doute dans l'esprit de plusieurs anesthésistes et éducateurs et de la plupart des candidats qui se présentent à l'oral.

De plus, les émotions engendrées augmentent cette sensation de méfiance du candidat. Habituellement, celui qui se présente à l'examen oral arrive à 30 ans. Sous l'aspect universitaire, la plupart des médecins sont supérieurs et très peu ont connu des échecs sérieux. Pour plusieurs, l'enjeu est énorme. Après un minimum de 13 années d'enseignement supérieur et une mise de fond considérable, la société a élevé l'étudiant(e) brillant(e) au niveau des êtres supérieurs; tout-à coup, il doit faire face à une possibilité réelle d'échec. Pour certains, cela signifie l'incapacité d'accéder à une poste déjà accepté au moment où ceux-ci deviennent de plus en plus difficiles à trouver. Dans certaines provinces, cela implique qu'il ne peuvent s'enregistrer auprès de la régie des services de santé ou même obtenir un permis d'exercice.

Ce sont là des situations particulièrement éprouvantes pour des résidents qui ont déjà subi le supplice de l'examen à choix multiple et qui ont progressé de façon satisfaisante en cours de formation comme l'attesteront les évaluations périodiques de leurs directeurs de programme.

Il faut aussi tenir compte du coût de l'examen oral. Que dire du temps et de l'énergie déployés par les examinateurs qui sacrifient des semaines de travail et déployent beaucoup d'efforts pour une rémunération symbolique? Pour le candidat, les frais d'inscription, de transport et de logement sont aussi des fardeaux lourds à porter.

Quelle est la valeur de ce mode d'évaluation et pourquoi devrions-nous le perpétuer? Eagle et al. soulignent que la compétence clinique que le jury tente d'évaluer comprend beaucoup plus que l'habileté du candidat à résoudre machinalement une situation imaginaire. Le processus est destiné à évaluer l'association à des connais- sances spécifiques et des activités interpersonnelles, d'habiletés cliniques acquises par l'expérience et intégrées pour la solution d'un problème médical. L'examen oral est l'épreuve ultime régie par un organisme national responsable de l'application des normes médicales (le Collège royal des médecins et chirurgiens du Canada) qui servent à déterminer si le candidat est devenu un anesthésiste complet.

Nous devons poser la question suivante: l'examen oral peut-il atteindre cet objectif? Le format diffère d'un pays à l'autre. La méthode américaine est impersonnelle et froide; elle n'alloue pas de temps à la réflexion et exige que, sur une période identique, les mêmes quesstions soient posées à tous les candidats. Comme le temps alloué est court, le raisonnement et la discussion ne tiennent pas de place aux yeux des examinateurs. La spécifité des réponses est primordiale. L'examen canadien débute sur une note générale, évolue et peut se fixer sur des sujets plus restreints selon la réponse. Ce qui fonctionne bien, vu le plus petit nombre de candidats et la présence de tous les membres du jury à la séance derévision et d'attribution des cotes à la fin de la journée. Contrairement à la méthode de l'American Board of Anesthesiology, cette personnalisation donne au candidat sujet à la nervosité et à la confusion une plus grande marge de sécurité. De plus, la présence d'un troisième examinateur qui joue le rôle de secrétaire offre la possibilité d'un tiers parti objectif en cas de litige.

Les auteurs décrivent les améliorations apportées à la validité et à la fiabilité du modèle américain, en particulier les standards exigés des examinateurs, les modifications aux programmes et les outils d'évaluation applicables tant aux candidats qu'aux examinateurs.

En adoptant cette nouvelle voie, l'examen oral canadien survivra en tant que méthode d'évaluation respectée. L'humiliation autrefois imposée par l'examinateur pour faire " grandir " le candidat est devenue chose du passé. Un examinateur ne peut maintenant couler un candidat parce qu'il utilise une technique différente de la sienne. D'abord et avant tout, l'éthique de l'examen doit reposer sur la collégialité. Le Collège royal des médecins et chirurgiens du Canada lui-même rapelle aux candidats que l'examen oral est le dernier pas du processus d'évaluation. Tous les autres obstacles surmontés, le directeur du programme croit que son pupille a atteint un niveau d'exercice digne de celui de l'associé (fellow). L'oral n'est que la reconnaissance de ce fait.

$\mathrm{Au}$ cours de la dernière décennie, on a pu constater un effort concerté pour insérer au processus un certain degré d'humanisme. Les examinateurs font un effort pour être bons, courtois et ponctuels. L'équipe prépare les questions à l'avance et l'usage d'une grille évite les répétitions et permet de couvrir un champ plus vaste de ques- 
tions. On évite de proposer des situations absurdes et complexes.

Est-ce que nécessaire de continuer les examens oraux?

La réponse est " oui " en autant:

a) qu'un effort constant sera fait pour renseigner les candidats sur le but de l'examen, sa structure et ses critères d'évaluation, la peur étant le pire ennemi du candidat à l'oral;

b) que le jury continuera de réviser, d'améliorer et de s'auto-enseigner en adoptant de nouvelles méthodes d'évaluation éprouvées pour évoluer vers une épreuve plus objective et plus valide;

c) que les jurés s'appliquent les mêmes critères rigoureux d'evaluation qu'aux candidats lorsqu'il évaluent la performance de ceux-ci.

Pour terminer, je suis d'accord avec les auteurs lorsquils énoncent que la force de l'examen oral réside dans le fait qu'il soit plutôt un outil d'enseignement qu'une technique de mesure. La rétroaction positive la plus importante provient des commentaires fréquents des candidats, une ou deux années après l'examen: la préparation à l'oral procure une meilleure connaissance de la spécialité, non seulement sur les plans théoriques et de techniques, mais aussi sur l'intégration des idées et leur communication. Aujourd'hui, je mets au défi les jurys d'examinateurs de créer un outil pour valider cette hypothèse et je suggère que celui-ci devienne nécessaire à ratification du maintien de l'examen oral. 